\title{
Prediksi Kesulitan Penempatan Jarum Spinal Berdasarkan Gambaran Radiologis dan Penanda Anatomis pada Pasien Bedah Urologi
}

\author{
Adhrie Sugiarto $^{1^{*}}$, Madeline Marpaung ${ }^{1}$ \\ 1. Departemen Anestesiologi dan Terapi Intensif, Fakultas Kedokteran Universitas Indonesia, \\ RSUPN Dr. Cipto Mangunkusumo, Jakarta, Indonesia
}

\begin{abstract}
ABSTRAK
Latar belakang: Penyuntikan berulang pada prosedur anestesi spinal berkaitan dengan tingginya angka komplikasi dan ketidaknyamanan pasien. Sistem prediksi pra-operatif yang akurat terhadap kesulitan penempatan jarum spinal dapat mengurangi insiden penyuntikan berulang sehingga mengurangi risiko komplikasi pada pasien. Penelitian ini bertujuan untuk mengetahui prediksi kesulitan penempatan jarum spinal berdasarkan gambaran radiologis dan penanda anatomis pada pasien bedah urologi.

Metode: Penelitian ini bersifat observasional analitik terhadap pasien bedah urologi yang menjalani anestesi spinal di Rumah Sakit Cipto Mangunkusumo pada bulan April-Mei 2015. Sebanyak 109 subjek diambil dengan metode consecutive sampling. Data pasien (usia, jenis kelamin, indeks massa tubuh, status fisik, gambaran radiologis vertebra lumbal, dan kualitas penanda anatomis tulang belakang), jumlah penusukan kulit, dan re-direksi jarum spinal, serta angka kesulitan penempatan jarum spinal dicatat. Kesulitan penempatan jarum spinal ditentukan berdasarkan jumlah penusukan kulit dan re-direksi jarum spinal. Variabel yang signifikan ditentukan melalui uji Pearson's Chi-square dan uji Fisher, kemudian dilanjutkan analisis multivariat dengan metode regresi logistik untuk melihat hubungan antara kesulitan penempatan jarum spinal dengan variabel-variabel yang signifikan.

Hasil: Faktor usia memiliki hubungan yang bermakna pada analisis bivariat $(p=0,028)$. Kualitas penanda anatomis dan gambaran radiologis vertebra lumbal memiliki nilai prediksi terhadap kesulitan penempatan jarum spinal ( $p=0,000$ dan $p=0,006)$. Hasil uji kalibrasi menunjukkan kualitas prediksi yang baik. Dari uji diskriminasi didapatkan AUC sebesar 0,84 (IK 95\% 0,751-0,929).

Simpulan: Kualitas penanda anatomis dan gambaran radiologis vertebra lumbal mampu memprediksi kesulitan penempatan jarum spinal dengan tepat pada pasien bedah urologi.
\end{abstract}

Kata Kunci: anestesi spinal, gambaran radiologis vertebra lumbal, kualitas penanda anatomis, prediksi kesulitan penempatan jarum spinal 


\title{
Predicting Difficulty of Spinal Needle Insertion Using Radiological Characteristics of The Lumbar Vertebra and Spinal Bony Landmarks in Urologic Patients
}

\author{
Adhrie Sugiarto $^{1 *}$, Madeline Marpaung ${ }^{1}$
}

1. Departement of Anesthesiology and IntensifCare, Faculty of Medicine, Universitas Indonesia, Dr. Cipto Mangunkusumo National General Hospital, Jakarta, Indonesia

*corresponding author

\begin{abstract}
Background: Multiple attempts at spinal puncture have been related to many complications and patient discomfort. Accurate preoperative prediction of spinal needle insertion difficulty would reduce the incidence of multiple puncture and minimize the complications consequently. This study was designed to determine the accuracy of lumbar vertebra radiological characteristics and spinal bony landmark quality in predicting the difficulty of spinal needle insertion in patients undergoing urologic procedure.

Methods: This was an analytic observational study in urologic patients scheduled for spinal anesthesia at Cipto Mangunkusumo hospital between April and May 2015. A total of 109 subjects were included in the study by consecutive sampling. Patient data (age, sex, body mass index, physical status, radiological characteristics of the lumbar vertebra, and quality of spinal bony landmark), number of skin puncture and needle redirection, and the prevalence of spinal needle insertion difficulty were recorded. The first skin puncture success and number of needle redirection were used to assess the difficulty. Significant variables were first determined by Pearson's Chi-square and Fisher test, and then multivariate analysis using logistic regression method tested the association of the skin puncture success and number of needle redirection with the significant variables.

Results: Age was significant only in bivariate analysis $(p=0,028)$. The quality of spinal bony landmark and the radiological characteristics of the lumbar vertebra had predictive value on spinal needle insertion difficulty ( $p=0,000$ and $p=0,006$ respectively). Calibration test showed that the prediction quality was good. The discrimination test resluted in AUC of 0,84 (CI 95\% 0,751 to 0,929).

Conclusion: The quality of spinal bony landmark and the radiological characteristics of the lumbar vertebra were accurate in predicting the difficulty of spinal needle insertion in patients undergoing urologic procedure.
\end{abstract}

Keywords: lumbar vertebra radiological characteristics; prediction of spinal needle insertion difficulty; spinal anesthesia; spinal bony landmark quality 


\section{PENDAHULUAN}

Anestesi spinal telah banyak digunakan untuk analgesia pada persalinan, seksio sesarea, prosedur ortopedi, urologi, analgesia perioperatif, dan tata laksana nyeri kronik. ${ }^{1}$ Jumlah prosedur anestesi spinal yang dilakukan di Rumah Sakit Cipto Mangunkusumo (RSCM) pada periode Juni 2013 sampai Mei 2014 adalah 1702 tindakan dari total 6629 pembiusan. Anestesi spinal pada kasus bedah urologi sebanyak 611 dari total 1612 operasi.

Teknik yang dilakukan berdasarkan penanda anatomis ini dapat menjadi sulit pada beberapa pasien. ${ }^{2}$ Angka kegagalan penempatan jarum spinal bervariasi antara 0,5 sampai $17 \%$ dan angka kesulitan berkisar 31-38\% sehingga menyebabkan penyuntikan berulang pada pasien. ${ }^{3}$

Penyuntikan berulang dapat menyebabkan ketidaknyamanan pasien, peningkatan insiden hematoma spinal, hematoma epidural, postdural puncture headache, dan trauma pada struktur saraf. ${ }^{3-6}$

Prediksi pra-operatif yang akurat terhadap kemungkinan kesulitan penempatan jarum spinal dapat mengurangi insiden penyuntikan berulang sehingga mengurangi risiko komplikasi terhadap pasien.3 Faktor-faktor yang berkontribusi terhadap ketepatan sistem prediksi kesulitan penempatan jarum spinal adalah usia, indeks massa tubuh (IMT), kelainan anatomis tulang belakang, penanda anatomis tulang spinal, posisi pasien pada saat penempatan jarum spinal, serta tingkat pengalaman pelaku spinal. . $^{3-5,7-9}$ Penelitian mengenai hal ini pernah dikemukakan oleh beberapa peneliti di Eropa dengan populasi orang Kaukasia. Terdapat perbedaan karakteristik tulang belakang antara ras Kaukasia dengan Asia yang berpengaruh terhadap hasil radiologi, pembedahan, dan desain instrumen yang akan digunakan pada vertebra lumbal orang Asia. ${ }^{10-12}$ Perbedaan ini menyebabkan perlunya penelitian mengenai sistem prediksi kesulitan penempatan jarum spinal pada populasi orang Indonesia. Penelitian ini bertujuan mengetahui ketepatan prediksi kesulitan penempatan jarum spinal berdasarkan gambaran radiologis dan penanda anatomis pada pasien bedah urologi.

\section{METODE PENELITIAN}

Penelitian ini merupakan studi observasional analitik potong lintang terhadap pasien bedah urologi. Kriteria penerimaan adalah pasien berusia di atas 18 tahun yang menjalani anestesi spinal, status fisik ASA I-III, memiliki gambaran radiologis vertebra lumbal sebelum diikutsertakan dalam penelitian, dan menandatangani lembar persetujuan penelitian. Kriteria penolakan adalah pasien yang menolak anestesi spinal, terdapat infeksi di tempat penyuntikan spinal, gangguan koagulasi, hipovolemia berat, peningkatan tekanan intrakranial, stenosis aorta berat, dan stenosis mitral berat. Kriteria pengeluaran adalah terjadinya kegawatdaruratan kardiorespirasi saat dilakukan anestesi spinal dan pasien tidak kooperatif saat dilakukan anestesi spinal. Penelitian dilakukan di Kamar Bedah Urologi RSCM periode April-Mei 2015 setelah mendapat persetujuan dari Komite Etik Penelitian Kesehatan FKUI/RSCM.

Sampel didapatkan secara consecutive sampling. Besar sampel dihitung berdasarkan rumus besar sampel untuk analisis multivariat. Pada penelitian pendahuluan yang dilakukan di Kamar Bedah Urologi RSCM periode November-Desember 2014 diketahui insiden kegagalan penempatan jarum spinal pada percobaan penusukan kulit pertama oleh residen anestesiologi yang telah menjalani masa pendidikan minimal tiga semester sebesar 30\%, maka besar sampel yang diperlukan sebesar 74 orang.

Faktor prediksi yang dinilai dalam penelitian ini adalah gambaran radiologis, kualitas penanda anatomis, kelompok usia, dan IMT. Hasil penelitian ini dicatat sebagai ada atau tidaknya kesulitan penempatan jarum spinal.

Peneliti melakukan kunjungan pra-anestesi satu hari sebelum operasi dan mencatat data demografik sampel serta menilai gambaran radiologis vertebra lumbal dan kualitas penanda anatomis tulang spinal. Data demografik yang dicatat adalah nama, usia, jenis kelamin, berat badan, tinggi badan, IMT, dan status fisik ASA. Gambaran radiologis yang dinilai adalah gambaran vertebra L1-L5 pada foto polos abdomen posisi subjek telentang. Kelainan radiologis vertebra lumbal ditandai dengan 
adanya osteofit atau kalsifikasi ligamen atau celah intervertebralis yang sempit pada foto polos abdomen. Kualitas penanda anatomis tulang spinal dinilai berdasarkan perabaan pada celah interspinosus menggunakan ibu jari tangan nondominan pada proyeksi L4-L5 di garis tengah vertebra dalam posisi pasien bersila. Kualitas perabaan pada celah interspinosus dikategorikan menjadi mudah dan sulit.

Saat pasien tiba di kamar bedah, dilakukan pemasangan monitor standar, nasal kanul dengan oksigen 3 liter/menit, kateter vena perifer ukuran $18 \mathrm{G}$, dan pemberian cairan kristaloid $5-7 \mathrm{ml} / \mathrm{kg}$ sebelum prosedur anestesi dimulai. Pelaku spinal adalah residen anestesiologi Fakultas Kedokteran Universitas Indonesia yang telah menjalani masa pendidikan minimal tiga semester dan telah melakukan prosedur anestesi spinal minimal 50 kali. Anestesi spinal dilakukan dalam posisi pasien duduk bersila dengan pendekatan median menggunakan jarum spinal Quincke nomor 27G di celah interspinosus L4-L5. Peneliti melakukan observasi terhadap aliran cairan serebrospinal di pangkal jarum dan mencatat variabel yang menandakan kesulitan penempatan jarum spinal, yaitu jumlah penusukan kulit lebih dari satu kali atau jumlah re-direksi jarum spinal $\geq 3$ kali sampai cairan serebrospinal mengalir.

Analisis data dilakukan dengan menggunakan perangkat lunak Statistical Product and Service Solutions (SPSS) 20. Uji Pearson's Chi-square dan uji Fisher digunakan untuk analisis bivariat masing-masing prediktor, kemudian metode regresi logistik digunakan untuk menilai kualitas variabel yang bermakna pada analisis bivariat dalam memprediksi kesulitan penempatan jarum spinal.

\section{HASIL PENELITIAN}

Selama periode penelitian dari April-Mei 2015 didapatkan 109 pasien yang diikutsertakan dalam penelitian, tidak ada pasien yang tergolong kriteria penolakan, dan tidak ada pasien yang dikeluarkan dari penelitian (Gambar 1).

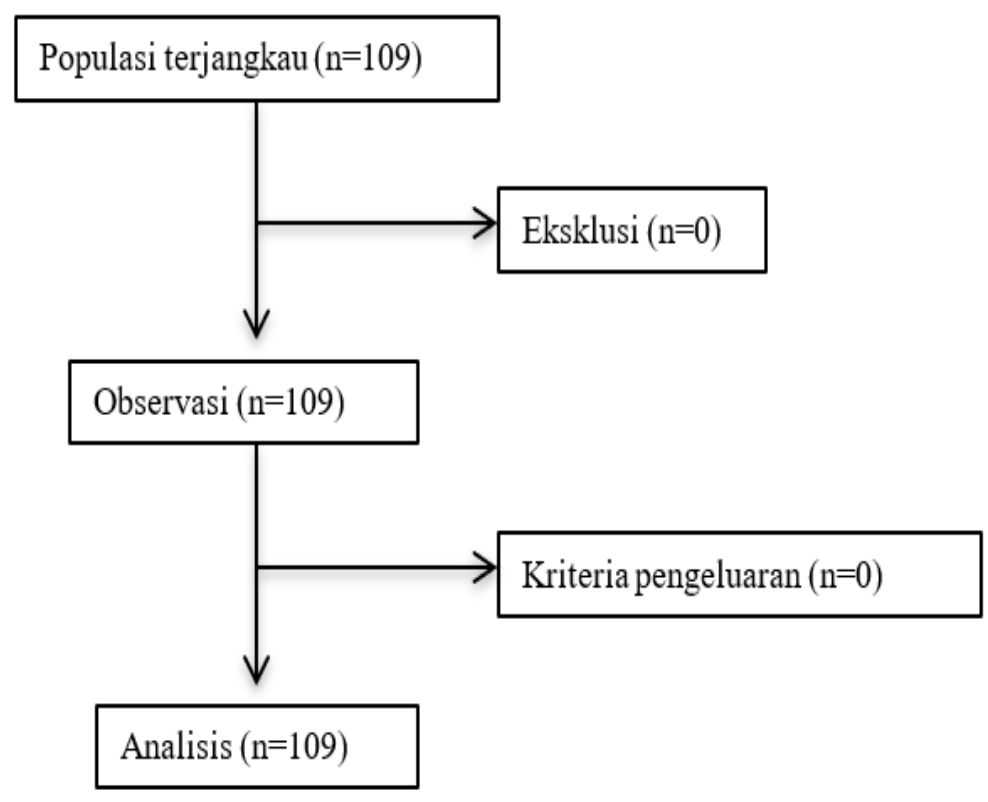

Gambar 1. Alur Penelitian

Data karakteristik subjek yang disajikan meliputi usia, jenis kelamin, index massa tubuh (IMT), status fisik ASA, jumlah pasien dengan kelainan radiologis vertebra lumbal, dan jumlah pasien dengan penanda anatomis sulit teraba. Jumlah sampel yang tergolong dalam kategori sulit penempatan jarum spinal sebanyak 38 orang (34,9\%). 
Tabel 1. Karakteristik Subjek Penelitian

\begin{tabular}{lc}
\hline Karakteristik & Jumlah $(\mathbf{n}=\mathbf{1 0 9})$ \\
\hline Jenis kelamin & \\
Perempuan (\%) & $65(59,6)$ \\
Laki-laki (\%) & $44(40,4)$ \\
Status fisik ASA & \\
$1(\%)$ & $6(5,5)$ \\
$2(\%)$ & $92(84,4)$ \\
$3(\%)$ & $11(10,1)$ \\
Usia (tahun) & \\
mean \pm SD & $51 \pm 11,6$ \\
IMT (kg/m2) & \\
median (min-maks) & $23,6(17,4-45,8)$ \\
Kelainan radiologis vertebra lumbal (\%) & $26(23,9)$ \\
Penanda anatomis sulit teraba (\%) & $25(22,9)$ \\
\hline
\end{tabular}

Faktor-faktor prediksi kesulitan penempatan jarum spinal yang dinilai pada penelitian ini meliputi gambaran radiologis, kualitas penanda anatomis, kelompok usia, dan IMT. Tabel 2 menunjukkan hubungan faktor-faktor prediktor tersebut terhadap kesulitan penempatan jarum spinal melalui analisis bivariat dengan uji Pearson's Chi-square dan uji alternatifnya.
Berdasarkan hasil analisis bivariat terdapat tiga variabel yang memiliki hubungan bermakna terhadap kesulitan penempatan jarum spinal, yaitu gambaran radiologis vertebra lumbal $(p<0,001)$, kualitas penanda anatomis $(p<0,001)$, dan kelompok usia $(p=0,028)$. Ketiga variabel ini memenuhi syarat untuk masuk ke dalam analisis multivariat. Hasil analisis multivariat

Tabel 2. Analisis Bivariat Gambaran Radiologis, Kualitas Penanda Anatomis, Kelompok Usia, dan IMT Terhadap Kesulitan Penempatan Jarum Spinal

\begin{tabular}{|c|c|c|c|c|c|c|c|c|c|}
\hline & & \multicolumn{2}{|c|}{ Sulit } & \multicolumn{2}{|c|}{ Tidak Sulit } & \multirow{2}{*}{$\mathrm{p}$} & \multirow{2}{*}{ OR } & \multicolumn{2}{|c|}{ IK 95\% } \\
\hline & & $\mathrm{N}$ & $\%$ & $\mathrm{n}$ & $\%$ & & & $\min$ & maks \\
\hline \multirow[t]{2}{*}{ Radiologis } & Kelainan & 19 & 73,1 & 7 & 26,9 & & & \multirow{2}{*}{3,341} & \multirow{2}{*}{25,016} \\
\hline & Normal & 19 & 22,9 & 64 & 77,1 & & & & \\
\hline \multirow[t]{2}{*}{ Perabaan landmark } & Sulit & 22 & 88 & 3 & 12 & \multirow{2}{*}{0,000} & \multirow{2}{*}{31,167} & \multirow{2}{*}{8,297} & \multirow{2}{*}{117,08} \\
\hline & Mudah & 16 & 19 & 68 & 81 & & & & \\
\hline \multirow[t]{2}{*}{ Usia (tahun) } & $\geq 65$ & 9 & 60 & 6 & 40 & \multirow{2}{*}{0,028} & \multirow{2}{*}{3,362} & \multirow{2}{*}{1,095} & \multirow{2}{*}{10,324} \\
\hline & $<65$ & 29 & 30,9 & 65 & 69,1 & & & & \\
\hline \multirow[t]{2}{*}{ IMT (kg/m2) } & $\geq 30$ & 4 & 40 & 6 & 60 & \multirow{2}{*}{0,737} & \multirow{2}{*}{1,275} & \multirow{2}{*}{0,337} & \multirow{2}{*}{4,826} \\
\hline & $<30$ & 34 & 34,3 & 65 & 65,7 & & & & \\
\hline
\end{tabular}

menunjukkan faktor yang memiliki nilai prediksi terhadap kesulitan penempatan jarum spinal adalah gambaran radiologis vertebra lumbal ( $p=0,006$; OR 21,797) dan kualitas penanda anatomis tulang belakang ( $p<0,001 ;$ OR 22,214). Uji kalibrasi dilakukan dengan Hosmer and Lemeshow test. Hasil uji kalibrasi menunjukkan gambaran radiologis dan kualitas penanda anatomis memiliki kualitas prediksi yang baik dari aspek kalibrasi dengan nilai signifikansi sebesar 0,104. Uji diskriminasi dilakukan dengan metode Receiver Operating Curve (ROC). Nilai AUC yang didapat dari kurva ROC adalah sebesar 0,84 (IK 95\% 0,751; 0,929). 
Tabel 3. Analisis Multivariat Gambaran Radiologis, Kualitas Penanda Anatomis, Dan Kelompok Usia Terhadap Kesulitan Penempatan Jarum Spinal

\begin{tabular}{llccccc}
\hline & \multicolumn{1}{c}{ Variabel } & \multirow{2}{*}{ Koefisien } & \multirow{2}{*}{} & \multirow{2}{*}{ OR } & \multicolumn{2}{c}{ IK 95\% } \\
\cline { 6 - 7 } & & & & & 1,520 & 16,985 \\
\hline Langkah 1 & Gambaran radiologis & & & & min & maks \\
& Kualitas penanda anatomis & 3,082 & 0,000 & 21,797 & 5,512 & 86,189 \\
& Kelompok usia & 0,466 & 0,562 & 1,594 & 0,329 & 7,713 \\
& Konstanta & $-1,827$ & 0,000 & 0,161 & & \\
Langkah 2 & Gambaran radiologis & 1,677 & 0,006 & 5,347 & 1,625 & 17,593 \\
& Kualitas penanda anatomis & 3,101 & 0,000 & 22,214 & 5,644 & 87,422 \\
& Konstanta & $-1,787$ & 0,000 & 0,168 & & \\
\hline
\end{tabular}

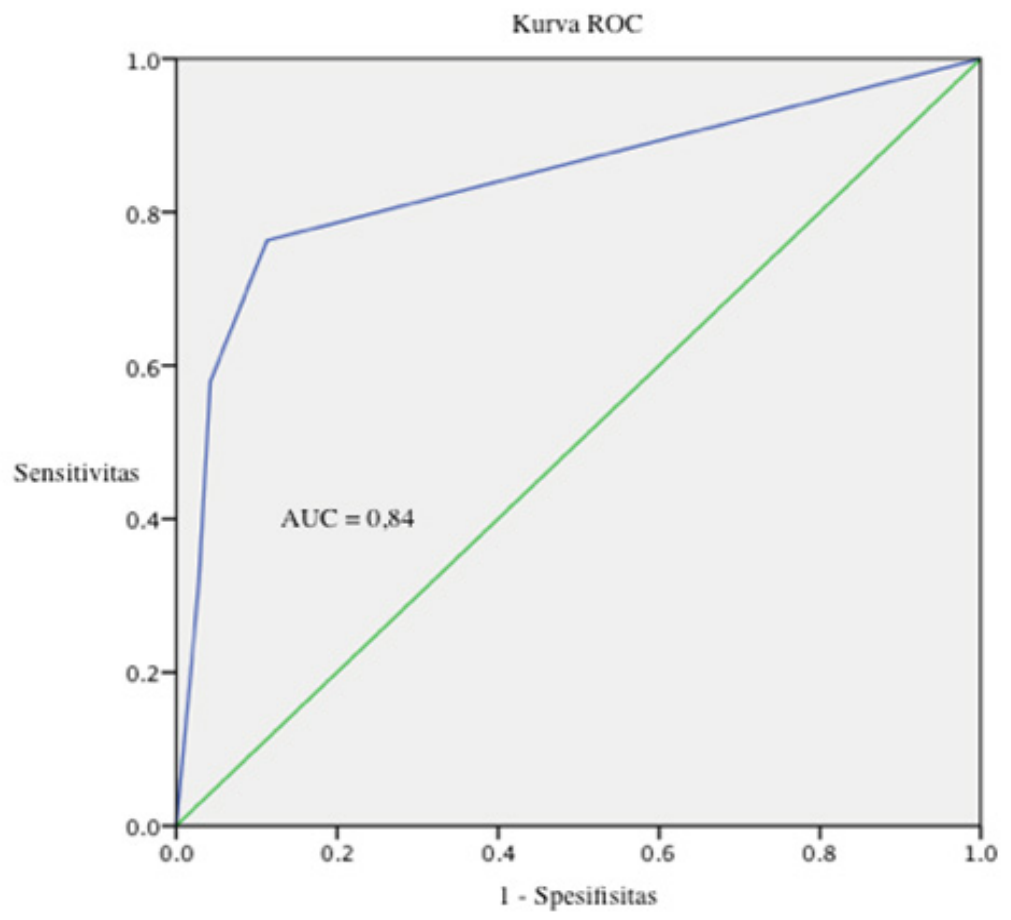

Gambar 2. Kurva ROC Prediksi Gambaran Radiologis dan Penanda Anatomis terhadap Kesulitan Penempatan Jarum Spinal

\section{PEMBAHASAN}

Penyuntikan jarum spinal berulang dikaitkan dengan tingginya komplikasi dan menyebabkan ketidaknyamanan pasien. Angka kejadian kesulitan penempatan jarum spinal dari penelitian sebelumnya bervariasi antara $31 \%$ sampai $38 \% .^{3}$ Pada penelitian ini angka kesulitan penempatan jarum spinal hampir sama dengan hasil dari penelitian-penelitian sebelumnya, yaitu $35 \%$.

Dari penelitian-penelitian sebelumnya didapatkan beberapa faktor risiko terjadinya kesulitan penempatan jarum spinal, yaitu usia tua, obesitas, adanya kelainan anatomis tulang belakang, penanda anatomis tulang belakang yang sulit teraba, posisi pasien saat penyuntikan jarum spinal, serta tingkat pengalaman pelaku spinal. $^{3-5,7-9,13}$ Faktor prediksi yang dinilai melalui penelitian ini adalah faktor yang berkaitan dengan karakteristik pasien.

Faktor pelaku spinal pada penelitian ini direstriksi berdasarkan lama pendidikan dan jumlah prosedur anestesi spinal yang telah dilakukan. 
Pemilihan ini mengacu pada penelitian oleh de Filho dkk. yang membandingkan angka keberhasilan spinal pada kelompok residen dan staf anestesi. Angka keberhasilan spinal lebih tinggi pada kelompok pelaku spinal dengan pengalaman di atas lima tahun. Di dalam kelompok pelaku spinal dengan pengalaman lima tahun ke bawah, terdapat perbedaan yang signifikan antara residen anestesiologi tahun pertama, residen tahun kedua, dan staf anestesiologi dengan pengalaman kerja lima tahun ke bawah. ${ }^{9}$ Praktik sehari-hari di RSCM juga menunjukkan bahwa paparan residen anestesiologi terhadap tindakan anestesi spinal paling banyak terjadi pada semester dua sampai semester tiga dan diharapkan jumlah tindakan anestesi spinal pada akhir semester tiga telah mencapai 50 kali, sesuai dengan syarat kompetensi dasar dari Kolegium Anestesiologi Indonesia.

Prediktor kesulitan penempatan jarum spinal yang dianalisis pada penelitian ini adalah gambaran radiologis, kualitas penanda anatomis, kelompok usia, dan IMT. Hasil analisis bivariat terhadap masing-masing prediktor menunjukkan bahwa gambaran radiologis, kualitas penanda anatomis, dan kelompok usia memiliki hubungan bermakna dengan kesulitan penempatan jarum spinal. Pada analisis multivariat selanjutnya didapatkan hanya gambaran radiologis vertebra lumbal dan kualitas penanda anatomis tulang belakang yang merupakan faktor prediksi independen terhadap kesulitan penempatan jarum spinal.

Gambaran radiologis vertebra lumbal memberikan informasi mengenai deformitas pada tulang belakang, yaitu osteofit, kalsifikasi ligamen, dan celah intervertebralis yang sempit., ${ }^{3,14}$ Osteofit dan kalsifikasi ligamen akan menyebabkan kekakuan pada kolumna vertebralis dan fusi tulang belakang sehingga mengganggu kemampuan fleksi tulang belakang. Gangguan fleksi menyebabkan ukuran foramen interlaminar menjadi kecil. Foramen interlaminar yang sempit menyebabkan kesulitan jarum spinal mencapai ruang subarakhnoid akibat kontak dengan lamina yang menyebabkan re-direksi jarum spinal berulang sampai penyuntikan kulit berulang. ${ }^{15,16}$

Beberapa penelitian menyebutkan gambaran radiologis vertebra lumbal merupakan prediktor independen terjadinya kesulitan penempatan jarum spinal. ${ }^{3,17}$ Penelitian oleh Garg dkk. ${ }^{18}$ menunjukkan pasien dengan kalsifikasi ligamen pada gambaran radiologis membutuhkan penggunaan introducer saat insersi jarum spinal. ${ }^{18}$ Pada penelitian ini, hasil analisis bivariat dan multivariat menunjukkan bahwa kelainan radiologis vertebra lumbal memiliki hubungan yang bermakna dengan kesulitan penempatan jarum spinal $(p=0,006)$. Dari perhitungan rasio odds, pasien dengan kelainan pada gambaran radiologis vertebra lumbal memiliki kemungkinan terjadinya kesulitan penempatan jarum spinal lima kali lebih besar dibandingkan pasien dengan gambaran radiologis vertebra lumbal yang normal.

Posisi subjek pada saat menjalani foto polos abdomen berbeda dengan posisi saat menjalani prosedur anestesi spinal. Pasien berbaring telentang pada saat dilakukan pemeriksaan foto polos abdomen dan melakukan fleksi tulang belakangpadasaattindakan anestesispinal. Fleksi tulang belakang menyebabkan terbukanya celah interspinosus dan celah interlaminar sehingga meningkatkan keberhasilan penempatan jarum spinal. Hal ini mungkin menjelaskan tidak terjadinya kesulitan penempatan jarum spinal pada beberapa pasien yang diprediksi sulit spinal berdasarkan gambaran radiologis.

Palpasi pada prosesus spinosus dan celah interspinosus bertujuan untuk menilai kualitas penanda anatomis tulang belakang. Penanda anatomis akan menjadi panduan untuk menentukan lokasi penyuntikan jarum spinal. Dari penelitian-penelitian sebelumnya, palpasi ini merupakan faktor kunci terhadap prediksi kesulitan teknik neuraksial. ${ }^{4,5,19,20}$ Kemampuan palpasi prosesus spinosus yang dikonfirmasi dengan pemeriksaan radiografi lumbal posteroanterior memiliki akurasi sebesar $69 \%{ }^{21}$ Penelitian lain yang dilakukan di Jepang juga menghasilkan nilai akurasi dari palpasi celah interspinosus sebesar $67 \%$. Data ini dapat digunakan pada penelitian ini karena terdapat kesamaan karakteristik tulang belakang pada sesama ras Asia. ${ }^{22}$

Pada penelitian ini kualitas penanda anatomis tulang belakang memiliki hubungan yang bermakna dengan kesulitan penempatan jarum 
spinal $(p<0,001)$. Hasil ini sesuai dengan hasil penelitian sebelumnya yang menyebutkan bahwa kualitas penanda anatomis berkaitan dengan keberhasilan anestesi spinal pada penyuntikan pertama. ${ }^{13}$ Atallah dkk. juga menyebutkan bahwa kualitas penanda anatomis merupakan salah satu faktor prediktor independen terhadap kesulitan penempatan jarum spinal. ${ }^{3}$ Perhitungan rasio odds dari penelitian ini menunjukkan bahwa pasien dengan penanda anatomis yang sulit teraba memiliki kemungkinan terjadinya kesulitan penempatan jarum spinal 22 kali lebih besar dibandingkan pasien dengan penanda anatomis yang mudah teraba.

Nilai interval kepercayaan 95\% untuk perabaan penanda anatomis pada penelitian ini adalah antara 5,6 sampai 87 . Rentang nilai yang cukup besar pada penelitian ini dapat disebabkan oleh sampling error, yaitu dari sisi jumlah sampel, dan random error, yaitu akibat variasi biologis pada populasi. Jumlah sampel yang digunakan pada penelitian ini cukup untuk menggambarkan sistem prediksi berdasarkan analisis multivariat, namun tidak cukup besar untuk menggambarkan interval kepercayaan pada populasi. Variasi kualitas penanda anatomis yang besar pada populasi terjangkau juga dapat menyebabkan besarnya nilai interval kepercayaan pada penelitian ini. Variasi ini masih mungkin disebabkan oleh perbedaan anatomi akibat keragaman suku di Indonesia. Perbedaan kelompok ras dapat menampilkan ciri fisik yang berbeda, salah satunya terletak pada pola tulang belakang.

Faktor usia pada analisis bivariat memiliki hubungan yang bermakna dengan kesulitan penempatan jarum spinal $(p=0,028)$. Pada pasien geriatri, umumnya terjadi penyakit degeneratif tulang belakang yang menyebabkan penyempitan celah interspinosus dan celah interlaminar akibat perubahan sklerotik, osifikasi ligamen interspinosus, hipertrofi sendi faset, dan kalsifikasi. Selain itu juga terjadi perubahan struktur pada ligamen flavum menjadi bentuk yang mudah mengalami osifikasi. Proses degenerasi juga terjadi pada diskus intervertebralis dan menyebabkan berkurangnya ketinggian diskus, sehingga terjadi tumpang tindih pada faset yang menyebabkan berkurangnya dimensi longitudinal dari foramen intervertebralis dan pemendekan ligamen flavum. ${ }^{23}$

Pada analisis multivariat, faktor usia tidak memiliki hubungan yang bermakna terhadap kesulitan penempatan jarum spinal $(p=0,562)$. Hal ini mungkin disebabkan karena faktor usia tidak secara langsung menyebabkan kesulitan penempatan jarum spinal. Proses degenerasi menyebabkan kelainan anatomis dan gangguan fleksi tulang belakang sehingga menyulitkan palpasi penanda anatomis dan menyempitkan celah interlaminar. ${ }^{23,24}$ Analisis multivariat memungkinkan terlihatnya efek dari beberapa variabel terhadap keluaran secara simultan. Pada analisis bivariat kemaknaan hubungan antara faktor usia dengan kesulitan penempatan jarum spinal dapat terjadi karena faktor perancu lain tidak direstriksi. Ketika masuk ke metode regresi logistik, faktor-faktor prediksi yang bermakna pada analisis bivariat dianalisis secara simultan sehingga faktor-faktor perancu dapat direstriksi dengan analisis multivariat. Dari analisis multivariat ini dapat dilihat bahwa usia bukan merupakan faktor prediksi independen terhadap kesulitan penempatan jarum spinal.

Nilai IMT pada penelitian ini tidak memiliki hubungan yang bermakna dengan kesulitan penempatan jarum spinal $(p=0,737)$. Hal tersebut mungkin terjadi karena IMT tidak dapat menggambarkan faktor-faktor yang memengaruhikesulitan penempatanjarumspinal seperti distribusi jaringan adiposa. Karakteristik subjek penelitian ini juga memengaruhi hasil tersebut. Distribusi subjek berdasarkan nilai IMT tidak normal dengan nilai rerata IMT $24 \mathrm{~kg} / \mathrm{m}^{2}$ dan nilai median $23,6 \mathrm{~kg} / \mathrm{m}^{2}\left(17,3-45,8 \mathrm{~kg} / \mathrm{m}^{2}\right)$. Dari seluruh subjek hanya terdapat satu pasien dengan nilai IMT yang ekstrem, yaitu $45,8 \mathrm{~kg} / \mathrm{m} 2$ sehingga tidak dapat mewakili populasi untuk menentukan hubungan antara tingginya nilai IMT dengan kesulitan penempatan jarum spinal. Hal lain yang mungkin berpengaruh adalah rendahnya angka kejadian obesitas pada pasien urologi pada usia tua.

Atallah dkk. dan Khoshrang menyebutkan bahwa gambaran radiologis vertebra lumbal dan kualitas penanda anatomis merupakan dua faktor independen terhadap kesulitan penempatan jarum spinal. ${ }^{3,17}$ Penelitian yang dilakukan di Kamar Bedah Urologi RSCM menunjukkan 
hasil yang sama. Uji kalibrasi dan diskriminasi menunjukkan kualitas model prediksi pada penelitian ini baik. Dari model prediksi yang didapat, kualitas penanda anatomis tulang belakang memiliki nilai prediksi yang lebih besar daripada gambaran radiologis vertebra lumbal terhadap kesulitan penempatan jarum spinal.

Gambaran radiologis vertebra lumbal dan kualitas penanda anatomis mempunyai nilai diagnostik yang kuat $(A \cup C 0,8-0,9)$, dengan nilai AUC sebesar 0,84 (IK 95\% 0,751-0,929). Nilai AUC tersebut memiliki arti apabila gambaran radiologis dan kualitas penanda anatomis digunakan untuk memprediksi kesulitan penempatan jarum spinal pada 100 pasien bedah urologi di RSCM, maka akan didapatkan kesimpulan yang tepat pada 84 pasien. Secara statistik, interpretasi nilai AUC tersebut berdasarkan klasifikasi kekuatan nilai diagnostik kuat (80\%-90\%). Penelitian yang dikemukakan oleh Atallah dkk. menghasilkan nilai AUC sebesar 0,77 $\pm 0,048$ pada kelompok pasien yang dilakukan anestesi spinal oleh staf senior dan nilai AUC sebesar 0,71 $\pm 0,05$ pada kelompok residen junior. ${ }^{3}$ Berdasarkan nilai AUC yang didapat pada penelitian ini, didapatkan bahwa diskriminasi rumus probabilitas yang diperoleh dapat digunakan untuk memprediksi kesulitan penempatan jarum spinal pada populasi pasien bedah urologi.

Aplikasi klinis hasil penelitian ini untuk praktik sehari-hari adalah pemeriksaan fisik untuk menilai deformitas tulang belakang dan kualitas penanda anatomis harus menjadi modalitas utama dalam evaluasi praoperatif. Pemeriksaan ini cukup sederhana, murah, dan memiliki nilai prediksi yang baik terhadap kesulitan penempatan jarum spinal. Kesulitan penempatan jarum spinal dapat mengakibatkan pemanjangan waktu yang dibutuhkan untuk prosedur anestesi, re-direksi jarum spinal, dan penyuntikan berulang yang meningkatkan risiko komplikasi dan ketidkanyamanan pasien. Pada pasien yang diprediksi akan mengalami kesulitan spinal, penggunaan modalitas penunjang seperti ultrasonografi dapat membantu penentuan celah spinal atau epidural. ${ }^{17}$

Gambaran radiologis vertebra lumbal juga memiliki nilai prediksi yang baik terhadap kesulitan penempatan jarum spinal.
Pemeriksaan ini tidak wajib dikerjakan pada semua pasien. Pada pasien yang sudah memiliki gambaran radiologis vertebra lumbal (misalnya, trauma atau operasi urologi), modalitas ini dapat dimanfaatkan untuk membantu prediksi kesulitan penempatan jarum spinal. ${ }^{17}$

Penelitian ini memiliki beberapa keterbatasan, antara lain karakteristik subjek yang distribusinya tidak normal berdasarkan kategori IMT dan terdapat satu pasien dengan nilai IMT yang ekstrem. Subjek pada penelitian ini tidak dapat mewakili populasi pasien dengan nilai IMT yang besar sehingga hasil analisis bivariat menunjukkan tidak ada hubungan yang bermakna antara nilai IMT dengan kesulitan penempatan jarum spinal.

Keterbatasan lain terdapat pada pelaku spinal. Meskipun pelaku spinal telah direstriksi berdasarkan tingkat pengalamannya, adanya variabilitas interindividu masih belum dapat dihindarkan. Hal ini ditunjang dengan data dari penelitian oleh de Filho dkk. yang menunjukkan adanya variabilitas interindividu pada kelompok ahli anestesi senior. ${ }^{8}$ Selain itu, masih terdapat kemungkinan bias prosedural. Meskipun penilaian radiologis hanya dievaluasi oleh peneliti sebelum tindakan anestesi spinal, faktor-faktor lain seperti kualitas penanda anatomis, usia, dan IMT juga diketahui oleh pelaku spinal. Hal ini dapat menyebabkan timbulnya asumsi subjektif dari pelaku spinal sehingga berpengaruh terhadap keberhasilan penempatan jarum spinal.

Gambaran radiologis vertebra lumbal diinterpretasi oleh peneliti setelah melakukan telaah kepustakaan mengenai kelainan radiologis vertebra lumbal yang menjadi prediktor kesulitan penempatan jarum spinal. Hal ini dapat menyebabkan terjadinya bias pada interpretasi hasil radiologis. Prosedur ini dilakukan karena pada praktik sehari-hari, interpretasi kelainan radiologis untuk keperluan tindakan spinal tidak rutin dikerjakan oleh ahli radiologi, sehingga ahli anestesi disarankan memiliki pengetahuan praktis mengenai gambaran radiologis yang berkaitan dengan tindakan spinal agar dapat memanfaatkan hasil pemeriksaan penunjang lebih baik. 


\section{SIMPULAN}

Gambaran radiologis dan penanda anatomis memiliki nilai prediksi yang baik terhadap kesulitan penempatan jarum spinal pada pasien bedah urologi.

\section{SARAN}

Perlu dilakukan penelitian mengenai faktor prediksi kesulitan penempatan jarum spinal dengan pembatasan yang lebih spesifik pada pelaku spinal dengan kemungkinan variabilitas interindividu yang lebih kecil. Perlu dilakukan penelitian mengenai keberhasilan teknik paramedian pada pasien dengan kelainan gambaran radiologis vertebra lumbal dan kualitas penanda anatomis yang sulit. Perlu dilakukan penelitian lanjutan untuk membuat sistem penilaian kesulitan penempatan jarum spinal berdasarkan masing-masing kategori kelainan radiologis vertebra lumbal.

\section{KONFLIK KEPENTINGAN}

Penulis menyatakan tidak ada konflik kepentingan dalam penulisan artikel ini.

\section{DAFTAR PUSTAKA}

1. Butterworth JF, Mackey DC, Wasnick JD. Spinal, epidural, \& caudal blocks. Dalam: Butterworth JF, Mackey DC, Wasnick JD, penyunting. Morgan \& mikhail's Clinical Anesthesiology. Edisi ke-5. New York: McGraw-Hill; 2013. h. 937-74.

2. Biswas BK, Agarwal B, Bhattarai B, Dey S, Bhattacharyya P. Straight versus flex back: Does it matter in spinal anaesthesia? Indian J Anaesth. 2012;56(3):259-64.

3. Atallah $M M$, Demian $A D$, Shorrab $A A$. Development of a difficulty score for spinal anaesthesia. Br J Anaesth. 2004;92(3):35460.

4. Garcia AM, Martí A, Rodriguez PM, Villamor M, Martínez A, Moral MV. Predictors of difficulty in neuroaxial block: A prospective study: 8AP1-6. Eur J Anaesthesiol. 2011;28:110.

5. Sprung J, Bourke DL, Grass J, Hammel J, Mascha E, Thomas P, dkk. Predicting the difficult neuraxial block: a prospective study.
Anesth Analg. 1999;89(2):384-9.

6. Lerner SM, Gutterman P, Jenkins F. Epidural hematoma and paraplegia after numerous lumbar punctures. Anesthesiology. 1973;39(5):550-1.

7. Soltani Mohammadi S, Hassani M, Marashi SM. Comparing the squatting position and traditional sitting position for ease of spinal needle placement: a randomized clinical trial. Anesth Pain Med. 2014;4(2):136-9.

8. Shankar H, Rajput K, Murugiah K. Correlation between spinous process dimensions and ease of spinal anaesthesia. Indian J Anaesth. 2012;56(3):250-4.

9. de Filho GR, Gomes HP, da Fonseca MH, Hoffman JC, Pederneiras SG, Garcia JH. Predictors of successful neuraxial block: a prospective study. Eur J Anaesthesiol. 2002;19(6):447-51.

10. Fang D, Cheung KM, Ruan D, Chan FL. Computed tomographic osteometry of the Asian lumbar spine. J Spinal Disord Tech. 1994;7(4):307-16.

11. Tan SH, Teo EC, Chua HC. Quantitative three-dimensional anatomy of lumbar vertebra in Singaporean Asians. Eur Spine J. 2002;11(2):152-8.

12. Aly T, Amin O. Geometrical dimensions and morphological study of the lumbar spinal canal in the normal Egyptian population. Orthopedics. 2013;36(2):229-34.

13. Ruzman T, Gulam D, Harsanji Drenjancevic I, Venzera-Azenic D, Ruzman N, Burazin J. Factors associated with difficult neuraxial blockade. Local Reg Anesth. 2014;7:47-52.

14. Fettes PD, Jansson JR, Wildsmith JA. Failed spinal anaesthesia: mechanisms, management, and prevention. $\mathrm{Br} J$ Anaesth. 2009;102(6):739-48.

15. Yilmaz M, Wong CA. Technique of neuraxial anesthesia. Dalam: Wong CA, penyunting. Spinal and epidural anesthesia. New York: McGraw-Hill; 2007. h. 27-73.

16. Prescher A. Anatomy and pathology of the aging spine. Eur J Radiol. 1998;27(3):181-95.

17. Khoshrang $H$, Falahatkar $S$, Heidarzadeh A, Abad M, Herfeh NR, Nabi BN. Predicting difficulty score for spinal anesthesia in transurethral lithotripsy surgery. Anesth Pain Med. 2014;4(4):16244. 
18. Garg R, Kumar A, Pandey R. Deformed spinal needle causing PDPH and dry tap due to blood clot. Local Reg Anesth. 2010;3:27-9.

19. Ellinas EH, Eastwood DC, Patel SN, MaitraD'Cruze AM, Ebert TJ. The effect of obesity on neuraxial technique difficulty in pregnant patients: a prospective, observational study. Anesth Analg. 2009;109(4):1225-31.

20. Chien I, Lu IC, Wang FY, Soo LY, Yu KL, Tang CS. Spinal process landmark as a predicting factor for difficult epidural block: a prospective study in Taiwanese patients. Kaohsiung J Med Sci. 2003;19(11):563-8.

21. Snider KT, Snider EJ, Degenhardt BF, Johnson JC, Kribs JW. Palpatory accuracy of lumbar spinous processes using multiple bony landmarks. J Manipulative Physiol Ther.
2001;34:306-13.

22. Tanaka K, Irikoma S, Kokubo S. Identification of the lumbar interspinous spaces by palpation and verified by X-rays. Rev Bras Anestesiol. 2013;63(3):245-8.

23. Kim JH, Song SY, Kim BJ. Predicting the difficulty in performing a neuraxial blockade. Korean J Anesthesiol. 2011;61(5):377-81.

24. Aylott CE, Puna R, Robertson PA, Walker C. Spinous process morphology: the effect of ageing through adulthood on spinous process size and relationship to sagittal alignment. Eur Spine J. 2012;21(5):1007-12.

25. Loeser JD, Treede R-D. The Kyoto protocol of Persentase operasi caesaria nin controlled trials. Medicine (Baltimore). 2016; 95: e3341. 